\title{
Main Socioenvironmental Impacts of Mining in the Caatinga Landscape in Northern Bahia/Brazil
}

\author{
Clecia Simone G. R. Pachecoํㅡ, Reinaldo Pacheco dos Santos ${ }^{2}$
}

\author{
${ }^{1}$ Department of Food Technology of the Federal Institute of Sertão Pernambucano, Brazil \\ ${ }^{2}$ Department of Geography of the University of Pernambuco, Brazil
}

\begin{abstract}
Mining is one of the basic sectors of Brazilian economy and it has contributed to the development of cities and small villages, since it is operated with social and environmental responsibility, based on the precepts of sustainable development. Much has been questioned about the social and environmental responsibility of mineral activity, raising questions about the impacts caused by the implementation of these projects. The present article aims to present the social and environmental reality of Quixaba village, in the county of Sento Sé, in the north of Bahia, with the voluntary exploration of an amethyst deposit, as well as to point out the main environmental impacts based on Environmental Law. It should be noted that this deposit has not been identified until then within the Brazilian mineralogical heritage, having been recently (re) discovered by people from the region. However, it is in the heart of semi-arid region, in a protected area called Boqueirão da Onça National Park, dominated by massifs and mountain ranges (more than 1,200 meters) in the center and north, and by plains to the south. This research is essentially based on the Geosystemic Theory, the Ecodynamic Method and the GTP Theory. Therefore, it is fundamental to develop conservation measures and sustainable management of protected environments, since landscapes are products and records of the geological evolution of the planet. Therefore, it is essential that local and environmental authorities understand the urgency of proper and responsible management of the areas explored by mining, mainly because the region has enormous geological, paleontological, archaeological, faunal, floristic and paleoenvironmental heritage.
\end{abstract}

Keywords - Mining; Environmental patrimony; APA; Paleoambientes; Impacts.

\section{INTRODUCTION}

Due to its continental dimensions and geological diversity, Brazil is a country with a huge mineral vocation and a major producer of basic inputs from mining. The Brazilian mineral production has grown in the last decades, because of significant investments made by mineral exploration companies, together with the efforts made by the federal and state governments in the execution of extensive programs of systematic geological surveys.

Mineral assets are one of the great non-renewable assets of geodiversity, being an important factor in sustainable development and improvement of the of Brazilians quality of life. However, the distribution of mineral resources is a metallogenic function tendency of tcrustal elements that formed the geological provinces of Brazil, being responsible for the great mineral diversity of these resources and their wide geographic distribution.

Based on these initial premises, it is pointed out that the present article aims to discuss the socio-environmental reality at Quixaba village, in a city callede Sento Sé, in the north of Bahia, with the voluntary exploration of an amethyst deposit, pointing out the main environmental impacts based on legislation. It is worth noting that this deposit has not been identified until the present time, in the Brazilian mineralogical map, having been (re) discovered (because it always existed) recently, by gold miners of the region. In order to discuss the highlighted points the law 7.805, from july18, 1989 will be used as basis. This law refers to the mining permit system, in the Code of Mining and Correlated Legislation, and CONAMA Resolution $N^{\circ}$. 237/97 in addition, we will base the discussions of the results on the Geosystemic Theory, on the Ecodynamic Method and on the GTP Theory.

Therefore, regarding to environmental impacts of mining, it should be considered that the practice of organized mining may cause less impacts and can be monitored and supervised by the public authority and environmental agencies. However, if mineral extraction occurs informally, without planning, control and inspection, it will become a source of large environmental liabilities.

This work aims to reflect on clandestine mineral extraction practices, their main socio-environmental impacts and, above all, on the need to legalize land use 
and occupation, in order to minimize the previously irreversible impacts caused by mineral extraction in the thesis area.

\section{HISTORIOGRAPHY OF MINERAL RESOURCES IN SENTO SÉ}

The county of Sento Sé (figure 1A), founded in 1832, is located in the north of Bahia, on the shores of Sobradinho Lake, in São Francisco river region, with an area of $12,699 \mathrm{~km}^{2}$ and a population of 41,102 (2014), away from the capital (Salvador) $689 \mathrm{~km}$. It has a semi-arid climate and is in the semi-arid region of the Brazilian Northeast, sheltering enormous geological, paleontological, archaeological, faunistic, floristic and paleoenvironmental patrimony (Figure 1B).
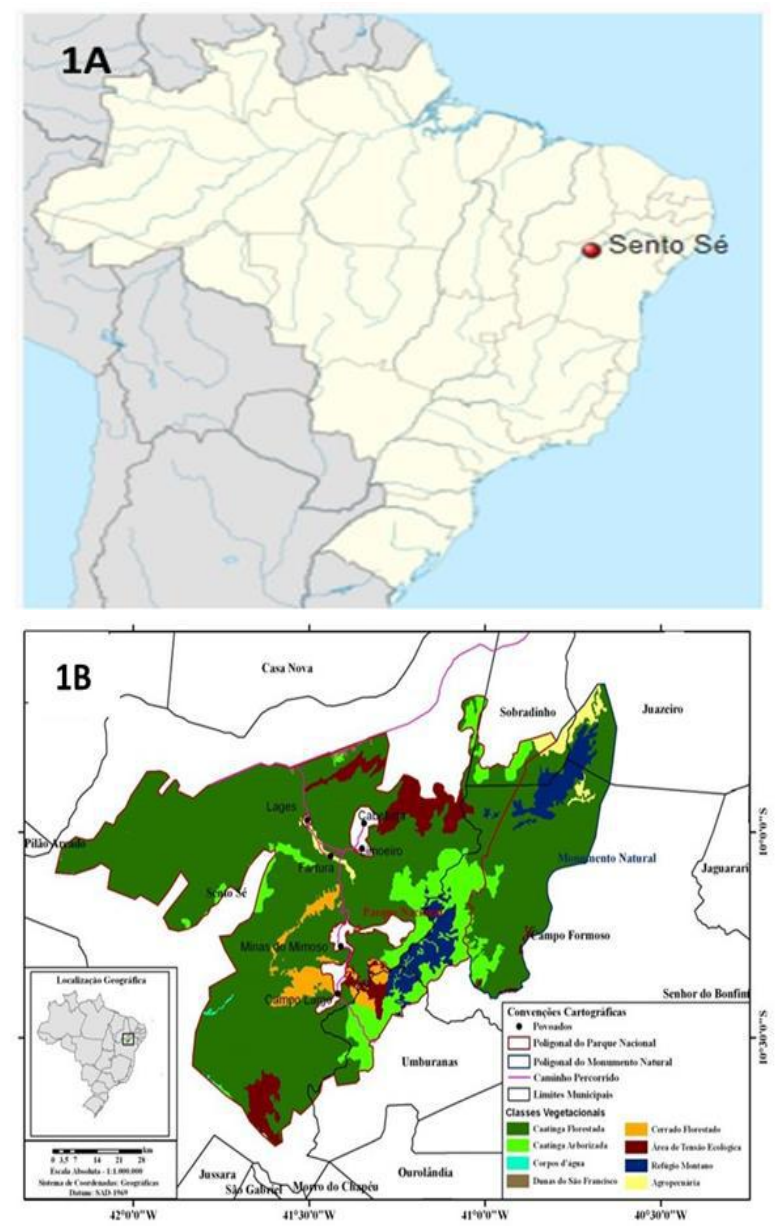

Fig.1A and B - Map of Senso Sé / BA and Natural Heritage Area

Source: KESTERING; ALVES; LIMA FILHO, (2013)

The historiography of Sento Sé reveals a legend, passed down from generation to generation, that a "bohemian" slave used to disappear from the slave quarters in the backward hours of servile labor. He never knew for sure where he was going, but when he returned he always brought nuggets of gold to present his master. It is said that at his death he took with him the secret of the place he had visited and had obtained gold. Apparently, the slave's secret had already been revealed, or at least deciphered, since the region now houses migrants from various parts of Brazil in search of precious stones.
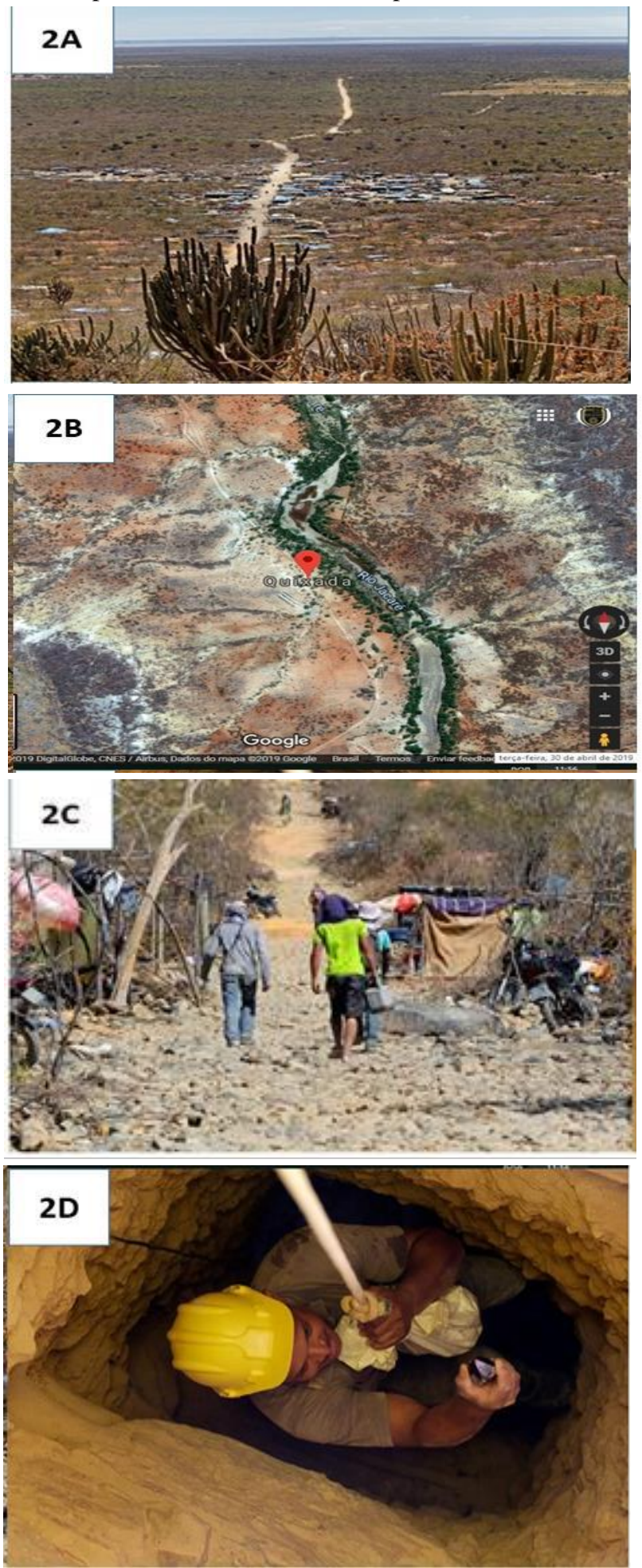

Fig.2 A, B, C and D - Overview of the Garimpo Source: Website A tarde Uol (2018)

The locality of Quixaba, which is $50 \mathrm{~km}$ away from the headquarters (Sento Sé), has a modified daily routine and the trade is overpowering with the arrival of the miners. 
At the top of Serra da Quixaba (Fig. 2A and B), there is a precious stone mining that was discovered by chance, and already has more than 8,000 people exploring it (Figure 2C). Since gems are in a difficult location (Figure 2D), it contributes even more to the risk of accidents, because miners do not use any Personal Protective Equipment (PPE) and there is not any on-site supervision.

The National Department of Mineral Production (DNPM) has already visited the gold digging and has made the necessary arrangements for its legalization of the mining that is still clandestine today. According to Law n. 7.805/89, Art. 3 "The granting of the mining permit depends on prior environmental licensing granted by the competent environmental agency". Thus, once the Public Power of Sento Sé meets all DNPM requests, the gold miner will need to organize themselves in a cooperative, duly registered and paying the mandatory taxes to Federal Government, since all the wealth that is in the subsoil is a domain of the Union, since "the mining permit shall be granted by the Director General of the National Department of Mineral Production (DNPM), who shall regulate, by means of an ordinance, the respective qualification procedure" (Article 4).

\section{MINING IN THE LIGHT OF BRAZILIAN ENVIRONMENTAL LAW}

According to Article 14 from Mining Code of 1969, mineral exploration is understood as the execution of the work required to define the mine, its evaluation and determination of feasibility of its economic exploitation (Mining Code and Correlated Legislation in Brazil, mineral resources have legal status, are part of the subsoil, and have a legal regime that is totally different from private land ownership. that mineral goods are of the Union and therefore can only be researched and exploited by companies that means an individualized and specific legal act for each one, obtaining a Mining Title, a Union concession granted by the National Department of Mineral Production (DNPM), on behalf of federal government.

Thus, the Mining Code (1967) removes the landowner's preference in the mineral exploration. In addition, the Brazilian Constitution requires an Environmental License (LA), forcing the company to carry out an Environmental Impact Study (EIA) to be able to operate later. Article 225, item IV, corroborates, reaffirming that it is necessary to require, in the form of the law, the EIA, for the installation of a work or activity potentially causing significant degradation of the environment.

Although there is still no systematic evidence for the entire Brazilian territory, perception of mining in the text on Agenda 21 of the Mineral Sector is not positive:
Mining is often cited as an aggressive activity of the environment, which cannot contribute to the sustainable development of the regions where it is located. This view portrays the reaction to the destructive use of environmental resources by modern society that degraded and polluted in the name of progress (p. 28).

Unfortunately, natural resources are finite, and after the closure of the mining activity, environmental impacts and soil degradation remain, exposed to open air, without any accountability in the process of remediation and restoration of the degraded area. According to Law $7,805 / 89$ in its Article 11, the DNPM will establish the areas of mining, taking into account the occurrence of mineral good, the interest of the mineral sector and social and environmental reasons. It also establishes that in areas of mining, the work should preferably be carried out in an associative way, through cooperatives (Art. 12), with the areas of garment being conditioned to the Prior License of the competent environmental agency (Art. 13).

\section{MATERIAL AND METHODS}

\section{1 Location of the research area}

The gold-digging of Serra da Quixaba, in the north of Bahia, is located in Boqueirão da Onça National Park (figure 3), a place that would give full protection to some 900,000 hectares in the heart of the Caatinga. The park in Boqueirão da Onça did not leave the paper, but it is in a region of difficult access, with little valued land, few roads, without paved asphalt and sparsely populated, with three inhabitants per thousand square kilometers.

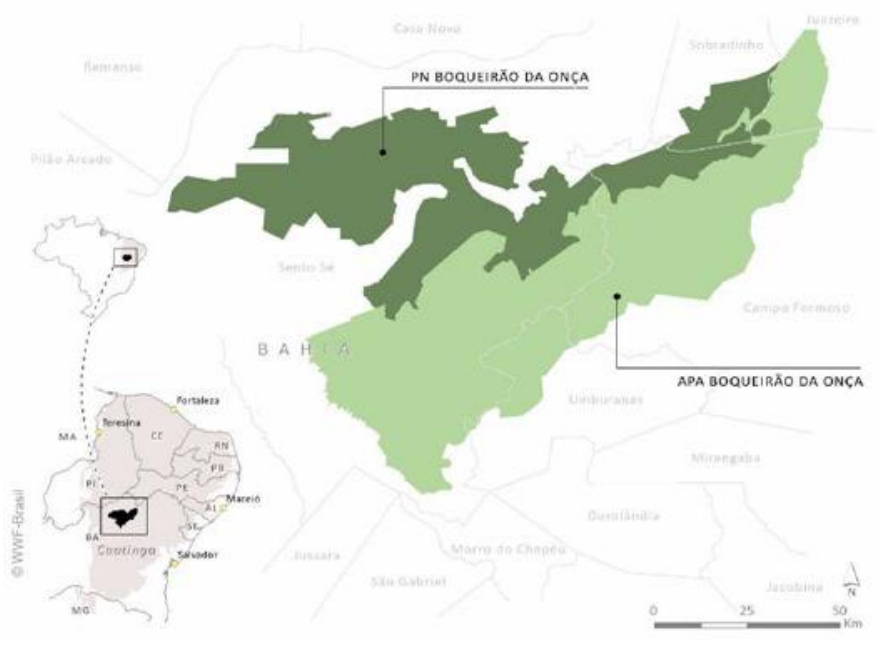

Fig.3: National Park

Source: World Wide Fundfor Nature (2018)

This region of northeastern sertão does not lack water and it is possible to become a large environmental reserve. 
Boqueirão da Onça is a refuge for several animals and preserves species of rare plants, besides having numerous rock formations and an immensity of 800 thousand hectares of native forest. The rare villages that exist are rustic, with pavement and stonewalls, narrow streets and small houses. The residents live on the exploitation of amethysts, which are found in artisanal mining. Many uninhabited lands being an ideal environment to protect the fauna/flora of the region.

The climate is semi-arid, but totally pleasant, due to the altitude. At more than one thousand meters of altitude, it is cold, in a region predominantly hot and dry. Boqueirão da Onça has one of the largest conserved caatinga areas on the planet. It is possible to find endemic species, originated in the region, besides gorges, despite the beauty, inspire solitude. An open-air laboratory where you can study/research. There are isolated points, far from everything, without tourism activities and preferred place of Ibama to release the animals seized in captivity.

\subsection{Methods}

For the study in thesis, it was sought to base essentially on the following theories/theoreticians:

a) Geosystemic Theory, which, according to conception, aims, a priori, at the integration of natural and anthropic variables, together with the second which merge the resources, uses and problems, which are configured in the synthesis step in homogeneous units, which thus leads to the conclusive stage of application, in which the real quality of the environment is clarified, resulting in a time analysis integrated space of the interrelationships society and environment in the construction of the land scape;

b) Ecodynamic Method, which states, "an ecodynamic unit is characterized by a certain dynamic of the environment that has more or less imperative repercussions on biocenoses" (p.32). Within the study of the ecodynamicism proposed by Tricart, this one categorizes the ecodynamic units in three, namely: stable means, means intergrades and strongly unstable means;

c) The GTP theory, aiming to re-approximate these three concepts to analyze how a given geographic space works in its entirety. Thus, essentially, it is a matter of understanding the interactions between different constituent elements to analyze the dialectic existing between the landscape, the territory and the geosystem. The visualization of the relationships between landscape elements should lead the researcher to understand the dynamics of the studied area and how to dialogue with the surrounding areas. In addition to the methodological assumptions described, the work is based on Law No. 7,805, which deals with the mining permit system, in the Mining and Correlated Legislation Code, and in CONAMA Resolutions.

\section{RESULTS AND DISCUSSIONS}

5.1 The impacts caused by the extraction of informal mining

\subsubsection{Socioeconomic impacts}

Growth boosts the creation of new ideas, arising from the need to create new products and improve existing ones, emphasizing the standard of living of the population, as well as the economic, and for that to happen, human capital is essential for innovative thinking and for manage the technology with knowledge. However, we should not confuse growth with development. Not always when there is growth, there is development.

The mining of Serra da Quixaba has provoked uncontrolled population growth (figure $4 \mathrm{~A}$ and $4 \mathrm{~B}$ ) in that district, so that it has made it possible for many to make large profits, and for others, the dream of becoming a millionaire. However, with the precarious conditions at the site (figure 5A and 5B), with improvised daily life, in the middle of the mountain range, with steep climbs and descents, there are many prospectors and people who have moved there, who are perishing with the thermal amplitudes (a heat that reaches up to $38^{\circ} \mathrm{C}$ a day, and a cold that can reach $20^{\circ} \mathrm{C}$ at night). Besides the lack of hygiene, security and privacy.

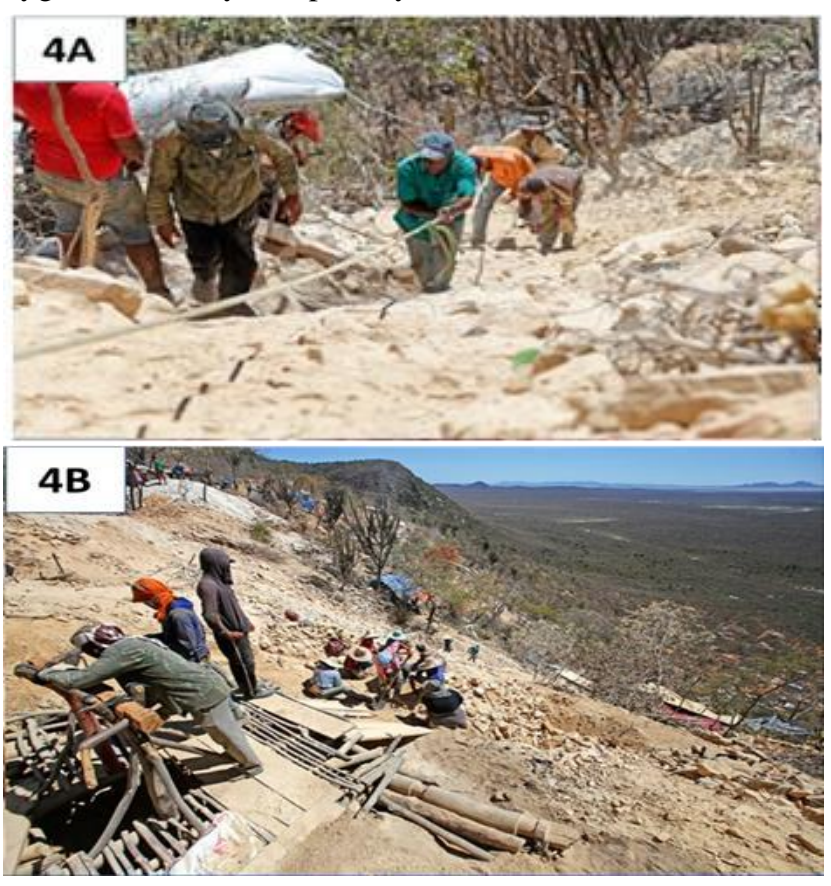



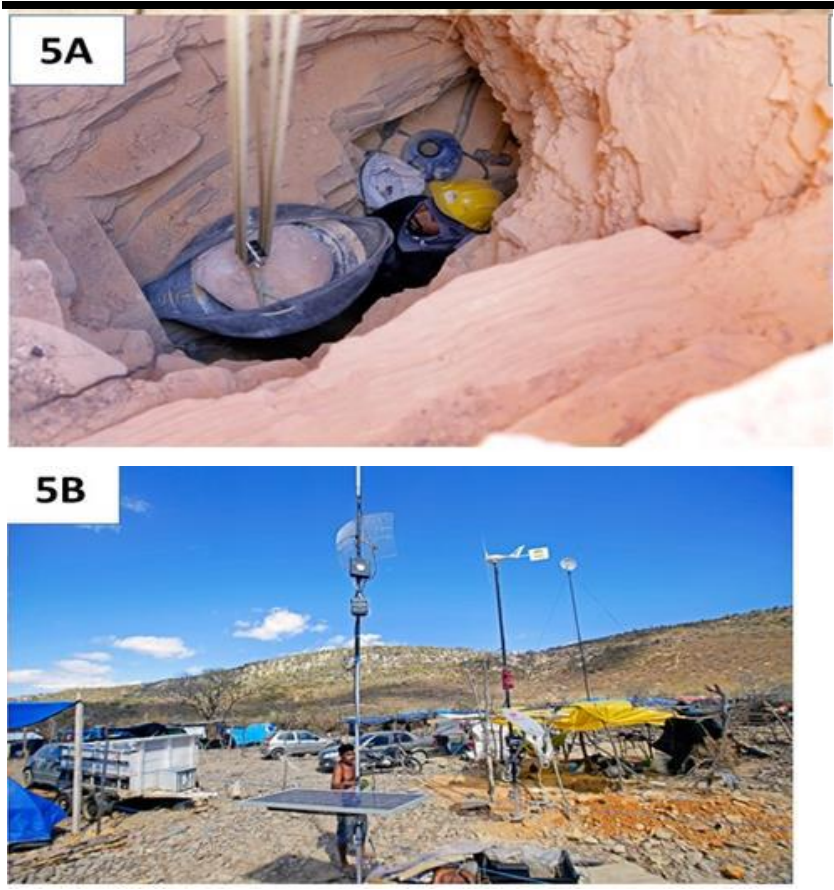

Fig. $4 A$ and $4 B ; 5 A$ and $5 B$ - Situation in loco Source: Website A tarde Uol (2018)

Those who actually make large profits are the international buyers (Chinese and Indians) who buy the stones and export for greater profits. Beyond them, the crossers, who market the stones with foreigners. In addition, the workers, who act with the manual strength, only acquire timid values with the sales, if compared with the hardness of the handles.

\subsubsection{Environmental impacts}

The environmental impacts in Serra da Quixaba mining area are uncountable. They range from the devastation of the caatinga biome to deforestation (Figure 6A) and opening of roads to reach the top of the mountain (Figure $6 \mathrm{~B})$, to the excavation of the soil in an unregulated way, causing dust, soot, landslides, lands lides and even deaths.

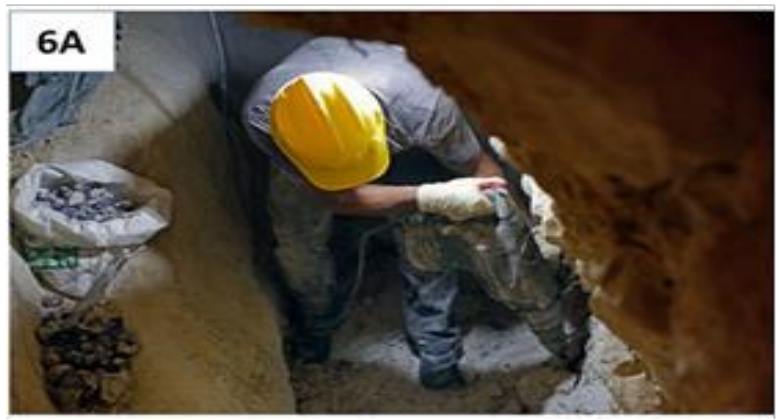

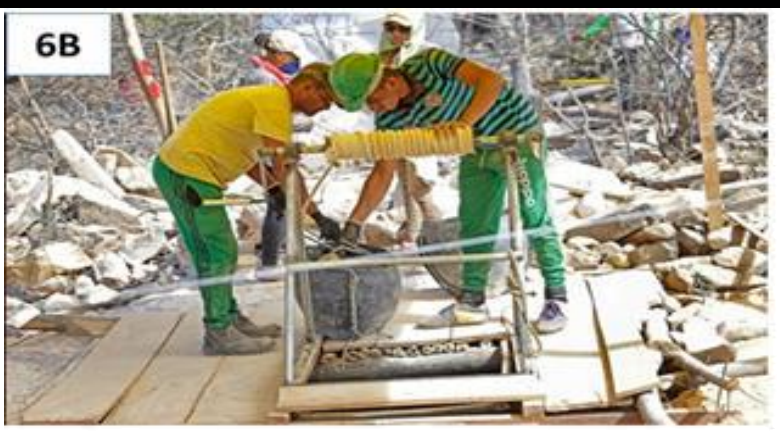

Fig.6A and $6 B$ - Situation in loco

Source: Website A tarde Uol (2018)

According to Article 1 of Resolution 001 of Conama, environmental impact is constituted:

Any change in physical, chemical and biological properties of the environment caused by any form of matter or energy resulting from human activities that directly or indirectly affect I - the health, safety and wellbeing of the population; II - social and economic activities; III - the biota; IV - the aesthetic and sanitary conditions of the environment; $V$ - the quality of environmental resources.

Therefore, mining and mineral exploitation are elements generated from incalculable impacts, since fauna and flora of the place suffer serious consequences. In Brazil, the main problems arising from mining can be classified into four categories: water pollution, air pollution, noise pollution, and subsidence. In the studied area, the flora is being degraded to give access to the mine, to be part of the gold-digging (construction of stairs, support grids for entrance in the cut, support for the descent of the workers, forks and supports for the barracks, etc.). Fauna is being unbalanced, by the avoidance of the animals, insects and birds of its habitat, due to the noise and daily movement of cars and people in the place.

\subsubsection{Accountability of public authorities and forms of remediation}

\subsubsection{Accountability}

According to Decree 97.632, mining enterprises are required to submit the Environmental Impact Assessment (EIA) and the Environmental Impact Report (RIMA), also to submit the Degraded Area Recovery Plan (PRAD) to the approval of the competent state environmental agency. The states and counties have constitutional power to legislate on mining and environment. In addition to these, Federal and State Public Prosecutors also oversee, is sue norms and guidelines, most of them conflicting with each other. Following is table (figure 7) of the governmental assignments related to environmental protection and mining planning. 
Distribution of Government Activities in Relation to

Environmental Protection and Mineral Exploration

\begin{tabular}{|c|c|c|c|}
\hline Mining Activity & Municipal Porrer & State Powrer & Federal Power \\
\hline $\begin{array}{l}\text { Application for a } \\
\text { Grant or License }\end{array}$ & $\begin{array}{l}\text { Laws of Use and } \\
\text { Occupation of Soil }\end{array}$ & $\begin{array}{l}\text { Enviironmental License by } \\
\text { Federal Legisiation }\end{array}$ & Defertal or Disallowance \\
\hline Mineral Search & $\begin{array}{l}\text { Lawis of Use and } \\
\text { Occupation of Soil }\end{array}$ & $\begin{array}{l}\text { Enviironmental License by } \\
\text { Federal Legisiation }\end{array}$ & Follow-up Approval Denial \\
\hline Mineral Mining & Business license & $\begin{array}{l}\text { Analysis of EIA / RIMA and } \\
\text { Envirionmental License by } \\
\text { Federal }\end{array}$ & $\begin{array}{l}\text { Legisilation Monitoring and } \\
\text { Oversight }\end{array}$ \\
\hline . Vining Recovery & $\begin{array}{l}\text { Definition of Future } \\
\text { Use of Soil }\end{array}$ & $\begin{array}{l}\text { Envirionmental License by } \\
\text { Federal Legisation }\end{array}$ & \\
\hline
\end{tabular}

Fig.7: Synthetic framework of government assignments (Translated)

Source: Adapted from Sintoni (1994)

The impacts caused by mining, combined with competition for land use and occupation, lead to socioenvironmental conflicts due to the lack of intervention regulation, which impedes the plurality of interests involved. The elucidation of the conflicts arising from the mining activity, essentially in Permanent Preservation Areas (PPAs) or in Conservation Units (CUs), requires a coordination of the public authorities that act in the locality, in agreement with the civil society and with companies of the branch, so that standards and procedures are implemented with clear and cohesive criteria, valuing the principles of sustainable development.

It is crucial that the areas affected by the implementation of mining be recovered, complying with what is stated in Article 225, $\S 2$ of the Constitution, which imposes on the one who exploits mineral resources the responsibility for recovering the environmental damages caused by the respective activity, obligation to recover the degraded environment, in accordance with the technical solution required by the competent public agency, in the form of a law.

On the basis of this premise, there is the question: in Serra da Quixaba, there is not yet an authorization to operate the mining. Will not the garimpeiros leave the region even before the legalization of operation, since from this, several taxes will be charged? It is a function of the DNPM, and especially of the Municipal Government, to monitor all processes, from EIA/RIMA, PRAD and Prior License, and Operation, in order to avoid abandonment of the mine by garimpeiros, without any environmental responsibility.

\subsubsection{Remediation}

Because of its continental dimensions and diversified geology, Brazil is a country with a huge mineral vocation and a major producer of basic inputs from mining.
Currently, it figures in the international scene alongside countries with a traditional mining vocation, such as Canada, Australia, South Africa and the United States. Figure 8A shows the map of mining activity in Brazil, where the distribution of these by almost all geoeconomic regions is observed, and Figure $8 \mathrm{~B}$ shows the mining areas within protected areas.
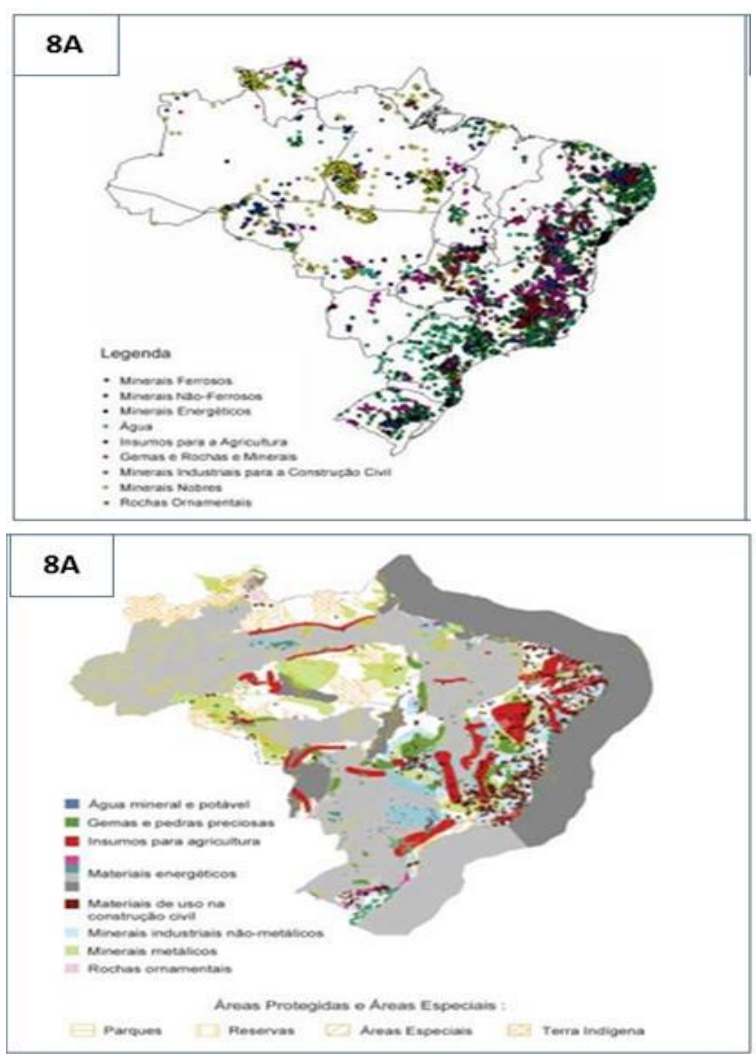

Fig.8 A and B - Mining Area Maps

Source: Farias (2002)

In this sense, the distribution of mineral resources is a function of the metallogenic vocation of crustal elements that form the geological provinces of Brazil, being responsible for the great mineral diversity of these resources and for their wide geographic distribution. However, it points out that organized mining causes less harmful impacts and is much more easily controlled by the public authorities. Moreover, mineral extraction carried out informally, without planning and control, is a source of great environmental liabilities. According to this author, control is very problematic, mainly because it involves parcels of the population that, deprived of this source of sustenance, are marginalized and excluded from any source of income. Thus, categorizes the environments as means: stable (areas that are still conserved), intergrades (areas that are in transition between stable and unstable) and strongly unstable (areas with high environmental degradation), it being possible to draw this categorization in the Serra da Quixaba mining area, according to figures $9 \mathrm{~A}, \mathrm{~B}$ and $\mathrm{C}$. 

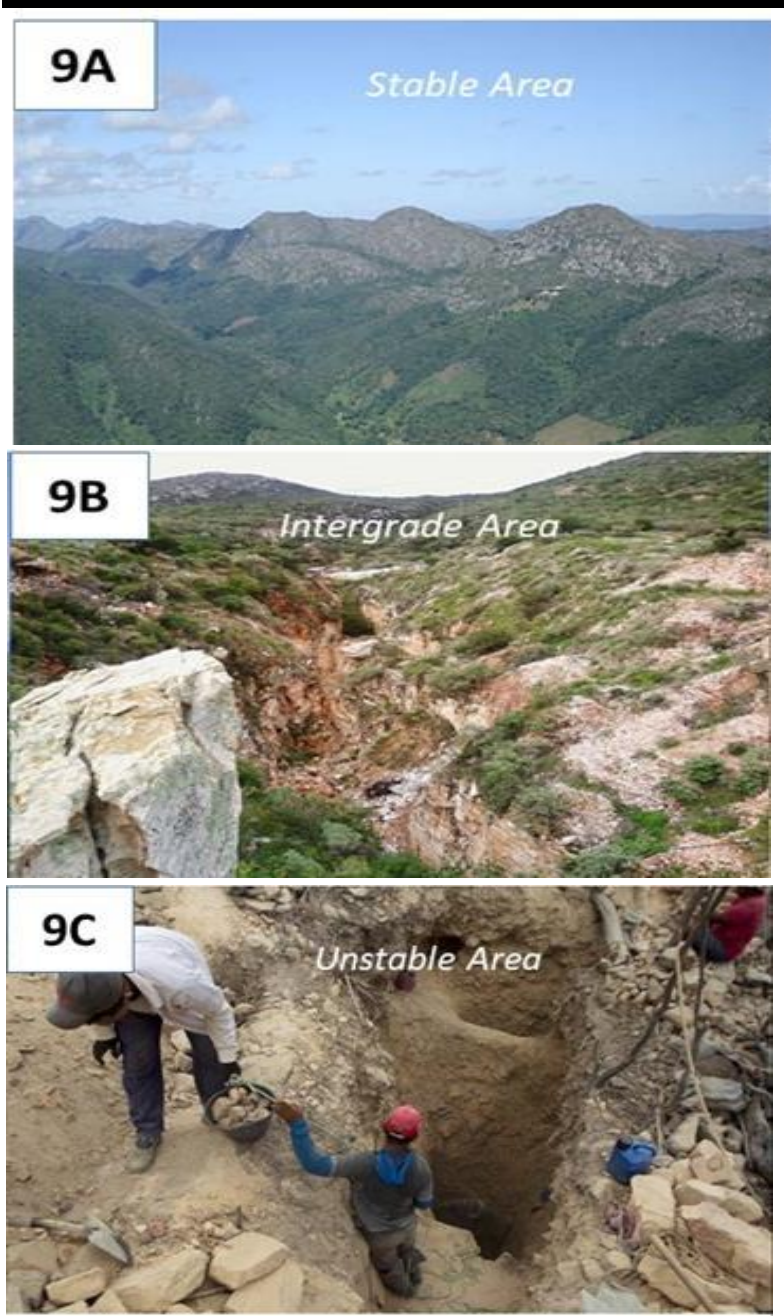

Fig.9A, 9B and 9C - Area Categorization according to the Tricart Theory

Source: Authors (2017)

Finally, it is important to point out conservation proposals in the dune geosystem, based on the characteristics of the ecoregion, since it is located in a protected area, where it would be Boqueirão da Onça National Park. In this conviction, it is suggested the creation of three strategic plans (Figure 10), for the three environments and, according to the GTP Theory.

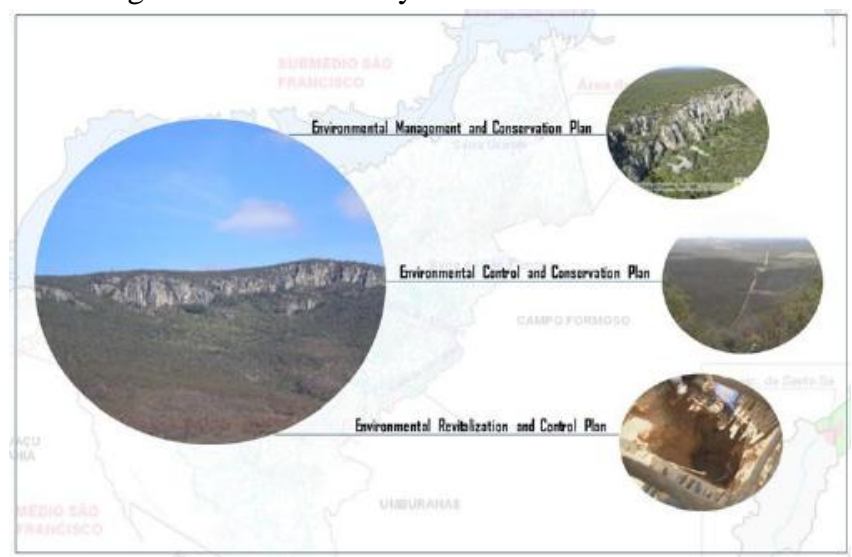

Fig.10: Strategic Plans
Source: Authors (2017)

Each suggested plan has its applicability according to the impaction of the area. The Environmental Management and Conservation Plan is applicable in areas that are still stable, aiming at conservation because it is a fragile and vulnerable environment due to climatic and socioeconomic conditions. The Environmental Control and Conservation Plan should be applied in areas that are in transition from the stable aspect to the middle intergrades. And the Plan of Revitalization and Environmental Conservation is the one that looks for strategies of revitalization/reforestation with native species of the caatinga biome, in the areas considered as strongly unstable and, from the results would draw a conservation control, analyzing the resilience capacity of the respective environments.

It should be emphasized that the proposed proposals should be applied by the Municipal Government of Sento Sé, in partnership with DNPM, with the State Government and with neighboring municipalities and districts affected by the impacts of mining.

According to the Resolution of CONAMA, n. 428 of December, in its Article 1 that the licensing of ventures of significant environmental impact that may affect specific Conservation Unit (UC) or its buffer zone (ZA), thus considered by the environmental licensing body, based on in Environmental Impact Assessment and Environmental Impact Report (EIA/RIMA), may only be granted after authorization from the body responsible for the management of the CU or, in the case of Private Natural Heritage Reserves (RPPN), by the body responsible for its creation. Therefore, any potentially impacting activity in this geosystem must be accompanied by an Environmental Impact Study and its Environmental Impact Report, in order to resolve any and irreversible impacts that may lead to greater imbalances in this territory.

\section{CONCLUSION}

The present article sought to discuss mineral exploration and its environmental impacts in Serra da Quixaba, in the north of Bahia, bringing the historiography of Sento Sé natural resources, especially mineral resources. Environmental issues were also discussed from a legislative perspective, since the related project is in an area with a proposal to implement a National Park named Boqueirão da Onça.

It is impossible to discuss environmental impacts in isolation, without linking it to social and economic impacts. In this way, the real profile of the region was traced in the present days with the arrival of the mining, as well as, it was pointed out the need of the public 
poweraccountability, the necessity of recovery of the degraded areas, suggesting proposals and plans of remediation of the area of mining.

Therefore, it is expected that this article can contribute to the environmental theme, mainly focused on legal issues of protection of the environment in the remediation of degradation by practice of mining.

\section{REFERENCES}

[1] SOTCHAVA, V. B. O estudo de geossistemas. São Paulo: Instituto de Geografia USP: 1977, 51 p. (Métodos em Questão, 16).

[2] TRICART, J. Ecodinâmica. Rio de Janeiro, IBGE, Diretoria Técnica, SUPREN, 91p, 1977.

[3] BERTRAND, G.; BERTRAND C. Uma Geografia Transversal e de Travessias: o meio ambiente através dos territórios e das temporalidades. Maringá: Mossoni, 2007.

[4] LOPES, L. S. de O.; ARAÚJO, J. L. L. Princípios e Estratégias de Geoconservação. OBSERVATORIUM: Revista Eletrônica de Geografia, v.3, n.7, p. 66-78, out. 2011.

[5] SILVA, C. R. da. Geodiversidade do Brasil: conhecer o passado, para entender o presente e prever o futuro. Rio de Janeiro: CPRM, 2008. 264 p.

[6] BRASIL. Lei n. 7.805 de 18 de julho de 1989. Disponível em: http://www2.camara.leg.br/legin/fed/lei/1989/lei7805-18-julho-1989-366155-norma-pl.html. Acesso em: 18 de jun. 2017.

[7] BRASIL. Código de mineração (1967). Código de mineração: e legislação correlata. 2. ed. - Brasília: Senado Federal, Subsecretaria de Edições Técnicas, 2011.

[8] CONSELHO NACIONAL DO MEIO AMBIENTE (BRASIL). RESOLUÇÕES DO CONAMA: Resoluções vigentes publicadas entre setembro de 1984 e janeiro de 2012. Ministério do Meio Ambiente. Brasília: MMA, 2012. P. 1126.

[9] KESTERING, C.; ALVES, R. de C.; LIMA FILHO, S. L. de. Boqueirão Do Riacho das Traíras, Sento Sé - Ba: Subtradição Sobradinho. Rupestreweb, 2013. Disponível em: http://www.rupestreweb.info/trairas.html. Acesso em: 20 jun. 2016.

[10] VIEIRA, R. L. Sento Sé: rico e ignoto. Bahia, Imprensa Oficial, s/d.

[11] BRASIL. Constituição da República Federativa do Brasil de 1988. Brasília: Senado Federal, Coordenação de Edições Técnicas, 2016. 496p. Disponível

em: https://www2.senado.leg.br/bdsf/bitstream/handle/id
1518231/CF88 Livro EC91 2016.pdf?sequence $=1$.

Acesso em 18 jun. 2017.

[12] SCLIAR, C. Agenda 21 e o setor mineral. Cadernos de Debate: Brasília, DF, 2004. Disponível em: http://www.mma.gov.br/index.php?ido=conteudo.m onta\&idEstrutura $=18 \&$ idConteudo $=1170 . \quad$ Acesso em: 15 jun. 2017.

[13] SOCIEDADE ESPELEOLÓGICA AZIMUTE (SEA). Proposta do Parque Nacional de Boqueirão da Onça. Disponível em: http://seazimute.blogspot.com.br/2012/11/parnaboqueirao-da-onca-parte-1.html . Acesso em: 15 abr. 2017.

[14] MONTEIRO, C. Geossistemas: a história de uma procura. São Paulo: Contexto, 2001.

[15] BRASIL. Decreto n. 97.632 de 10 de abril de 1969. Disponível em: http://www2.camara.leg.br/legin/fed/decret/1989/dec reto-97632-10-abril-1989-448270-norma-pe.html. Acesso em: 18 jun. 2017.

[16] FARIAS, C. E. G. Relatório Preparado para o CGEE/PNUD. S/L, 2002, 40p.

[17] SINTONI, A. A mineração no cenário do município de São Paulo: mercado e novas tecnologias. In: I Encontro de Mineração no Município de São Paulo. Anais... São Paulo: Secretaria das Administrações Regionais da Prefeitura do Municipal de São Paulo, 1994. p. 31-42.

[18] PACHECO, C. S. G. R. Ecodinâmica da Paisagem Paleodunar do Médio Rio São Francisco/BA: em defesa das fronteiras agredidas. Dissertação de Mestrado. Instituto de Tecnologia de Pernambuco (ITEP). Recife/PE, 2014,153 